\title{
Licensing research tool patents
}

\author{
Patent holders often seek royalties on the sales of products developed using their tools, \\ but how broadly should "reach-through" claims be applied?
}

Gerald J. Flattmann and Jonathan M. Kaplan

$R$ esearch tool patents typically claim methods or compositions used to discover novel, biologically important compounds and therapeutics. Patentees often try to maximize the rewards of their innovation by conditioning licenses to research tool patents on royalties from sales of commercial products that may ultimately be discovered and brought to market using the patented tools. Such royalties are called "reach-through royalties," and arrangements for them have become increasingly common in the biotechnology and pharmaceutical industries. However, they may be anticompetitive and unenforceable if the patentee is effectively seeking royalties on more than it invented, disclosed, and taught in its patent.

Entitlement to reach-through royalties on research tool patents has become a matter of increasing concern for biotechnology and pharmaceutical companies alike. Hundreds of millions of dollars in potential royalties and profits on blockbuster drugs and other therapies are at stake, as well as traditional notions of scientific progress, which may be impeded by an increasingly complex and restrictive intellectual property regime.

To date, the courts have provided surprisingly little guidance to researchers and industry concerning these important issues, and most pharmaceutical companies have taken the cautious approach of securing licenses to research tool patents used in the development of products in their commercial pipelines. The validity and enforceability of these licenses (and the royalty streams they represent) have yet to be determined. In this article, we review the legal framework relevant to this issue, and the traditional bounds of patent scope, enforceability, and licensing. We also offer some recommendations to potential licensors and licensees of research tool patents.

\section{Claim scope and reach-through royalties}

Owners of patents directed to research tools naturally seek the highest possible

Gerald J. Flattmann is a partner and Jonathan M. Kaplan is an associate at Fish \& Neave, 1251 Avenue of the Americas, New York, NY 10020 (gflattmann@fishneave.com). financial return on their research and development efforts. To maximize that return, patentees typically negotiate licenses based on flat fees or milestone payments due at various stages of drug development that rely on their patented research tools. More recently, however, many research tool patentees have been seeking reach-through royalties based on sales of drugs and therapeutics ultimately developed using their research tools. Such licensing regimens bring up questions of how broadly claims to research tools ought to be applied and what royalty base they ought to command. The narrow application of such claims may limit patentees to reach only those methods and compositions specifically disclosed and claimed in a patent. In contrast, the broader application of such claims might also reach compositions unidentified at the time of the filing of the patent application, but discoverable through the use of the claimed research tool. Such broad application would allow patentees to command reach-through royalties ${ }^{1}$ based on sales of undisclosed compositions discovered using their claimed methods.

Reach-through royalty licenses are increasingly common because (i) they are more profitable than licenses based solely on sales or use of the research tool, (ii) they may be easier to enforce than licenses based solely on sales or uses of the research tool, and (iii) they potentially maximize the patentee's return on investment in otherwise limited markets (for example, if only one or a few potential licensees conduct experiments using their patented tools).

Some reach-through royalty arrangements, however, may be improper. The patent statute requires that patent applications (also known as "specifications") contain a written description of the invention, essentially to show that an inventor was in possession of the invention as claimed at the time the application was filed (35 USC $\$$ $112)^{2}$. Arguably, reach-through royalty arrangements should not award patentees royalties based on sales of products that lack descriptive support in the specification.

The specification must also enable a person skilled in the art to make and use the invention without undue experimentation.
This means that the teachings of the specification must be "commensurate in scope" with the invention as claimed. If a person of skill in the art could not practice a claimed invention by following the teachings of the specification combined with the knowledge in the art at the time the application was filed, the claim would fail for lack of enablement ${ }^{3}$. Arguably, reach-through royalty arrangements should not award patentees royalties based on the sale of products that were not enabled by the disclosure of the specification at the time of the invention.

In sum, patents that adequately describe and enable a method or tool for discovering bioactive compounds or using specific screening systems under certain experimental conditions may not describe and enable the commercial products that directly result from the licensee's use of those methods and tools. The tension between the indispensability of licensed research tools to drug development and the limitations of the underlying research tool patents will likely be at the center of the legal debate over the validity and enforceability of reach-through licenses.

\section{Conflicting public policies: patent protection versus patent misuse}

Research tool developers are left to determine the proper scope of their research tool patents and what the proper scope of their licenses ought to be. It is well established that innovation should be rewarded under the patent statute. However, the licensing and enforcement of patents on research tools raise unique issues in the biotechnology and pharmaceutical fields, where relatively few products reach the market annually and the cost of getting them there is often extraordinarily high ${ }^{4}$.

As a matter of public policy, patents should not be construed to cover subject matter beyond the scope of what they disclose and claim. However, some in the biotechnology and pharmaceutical industries have attempted to extend the reach of their patents to do just that, by seeking licenses based on sales of products potentially discoverable using the claimed methods, but neither claimed nor supported by the disclosure of their patents. Overbroad 
enforcement and licensing of such research tool patents may be anticompetitive; instead of rewarding innovation by the grant of a limited monopoly, it may stifle subsequent innovation and discovery by making the use of such tools prohibitive or unduly expensive. Potentially anticompetitive behavior arising from such overbroad application of research tool patents can manifest itself in the form of (i) overly expensive licensing schemes; (ii) coercive licensing practices ${ }^{5}$; (iii) attempted foreclosure of subsequent research ${ }^{6}$; or (iv) creation of barriers to the entry of other firms into a field of scientific investigation or research ${ }^{6}$.

Restraints in trade based on the use of intellectual property come in the familiar flavors embodied by the antitrust laws. One type of restraint relating specifically to patents, known as "patent misuse," is a flexible doctrine that broadly condemns "every use of a patent as a means of obtaining a limited monopoly of unpatented material." $\mathrm{A}$ misused patent is unenforceable against alleged infringers until affirmative steps are taken to counteract the effects of the misuse. A showing of misuse, typically an affirmative defense to a suit for patent infringement, requires that the alleged infringer prove that the patentee has impermissibly broadened the "physical or temporal scope" of the patent grant with anticompetitive effect. Arguably, licensing arrangements that employ reach-through royalties may impermissibly broaden the scope of research tool patents if they reach subject matter neither contemplated by the inventor at the time of filing of the patent application nor adequately disclosed under 35 USC $\$ 112$. In sum, because reach-through royalty arrangements tie royalties from a commercial product to a research tool patent that does not itself cover that product, they may be subject to scrutiny under the patent misuse doctrine and the antitrust laws.

Not all reach-through royalty arrangements are alike. The question of whether a particular arrangement constitutes an impermissible broadening of the patent grant can only be answered in the context of the specific disclosure and claims of the patent, the nature of the commercial product at issue, and the specific terms of the license. If a patent disclosure contains an enabling description of the commercial product (or a genus of similar products) or if the product is explicitly claimed, then a licensing arrangement directed to that product is likely valid and enforceable. On the other hand, reachthrough licensing arrangements may be unenforceable in the absence of such teachings and claims. Notably, the US Supreme Court has traditionally rejected licenses conditioned on the payment of royalties based on subject matter the patent does not teach or claim ${ }^{8}$. Thus, patentees may potentially engage in misuse if they coerce prospective licensees into accepting licenses conditioned on the payment of royalties based on sales of commercial products that are not claimed or lack support in their patent.

Despite the increasing number of reachthrough royalty arrangements being negotiated today, there is surprisingly little case law regarding their scope and enforceability. Two relevant cases are discussed below.

\section{Sibia v. Cadus}

The first of two recent cases that provide some useful insights into how courts may treat reach-through licenses in the future is Sibia Neurosciences v. Cadus Pharmaceutical ${ }^{9}$. After a six-week trial, a California jury returned a verdict awarding Sibia a royalty of $\$ 18$ million based on its finding that Cadus's products infringed Sibia's research tool patent ${ }^{10}$ directed to certain methods of drug discovery.

The '629 patent, issued on March 28, 1995 to Harpold et al., broadly disclosed, among other things: " $[\mathrm{N}]$ ovel recombinant cells which are useful for assaying compounds for their agonist or antagonist activity with respect to specific ion channels and/or specific cell surface localized receptors ... rapid, reliable methods to identify compounds which interact with, and thereby affect the function of, specific ion channels and/or specific cell surface-localized receptors; [and] rapid reliable methods to determine if cells are producing specific functional ion channels and/or cell specific functional surface-localized receptors."

The specification listed as prophetic examples scores of ion channels and cell surface receptors that could be used in the disclosed methods. The ' 629 patent also disclosed as actual examples (i) the activation of the M1 muscarinic receptor by its agonist carbamylcholine in the presence or absence of its antagonist atropine; and (ii) the activation of gene expression by carbachol, bovine serum, or atropine.

Notably, the ' 629 patent claimed research tools rather than pharmaceutical compositions discoverable through the use of those tools. These research tools were recombinant cells and assays useful for identification of one or more pharmaceutical compositions directed to specific, clinically relevant diseases. The claims of the ' 629 patent broadly recited a "method for identifying compounds that modulate cell surface proteinmediated activity..." The patent contained no claims to products or compositions identifiable through that claimed method.

Sibia's damages award was based on Cadus's actual and potential profits on its commercialized products. The propriety of basing Sibia's damages on Cadus's sales of its commercialized products was resolved in Sibia's favor at the trial court level. However, it was never ultimately resolved because the jury verdict was overturned by the Court of Appeals for the Federal Circuit on different grounds-the Federal Circuit found that Sibia's claims were invalid because they were obvious over the prior $\operatorname{art}^{11}$.

\section{Bayer v. Housey}

The second recent case that may provide guidance to the biotechnology and pharmaceutical industries in negotiating research tool patent licenses is Bayer AG v. Housey Pharmaceuticals. Bayer filed suit seeking a declaratory judgment that defendant Housey Pharmaceuticals' patents were invalid, unenforceable, and not infringed ${ }^{12}$. Housey's US patent 4,980,281 ("the '281 patent") relates to a general screening method for the discovery and identification of both inhibitors and activators of enzymes, receptors, and other proteins. Specifically, one of its claims is directed to: "A method of determining whether a substance is an inhibitor or activator of a protein whose production by a cell evokes a responsive change in a phenotypic characteristic other than the level of said protein in said cell per se, comprising..." The specification of the '281 patent disclosed few substances that may act as inhibitors or activators and only a handful of target proteins.

Bayer alleged that Housey engaged in patent misuse by demanding a license with terms that would require substantial royalties based on Bayer's total research and development budget and total sales revenues for any commercialized products that Housey contended were developed using its patented method ${ }^{13}$. Notably, the court declined to dismiss Bayer's patent misuse defense: "Certain practices ... may constitute [patent] misuse if a court determines that such practices do not reasonably relate to the subject matter within the scope of the patent claims." ${ }^{14}$

Because Bayer's patent misuse claim has not been decided on the merits, the court has yet to provide guidance on which elements of Housey's licensing practices may constitute patent misuse. However, the Court's refusal to dismiss the claim indicates that under certain circumstances attempts to license research tool patents with reachthrough royalty provisions could constitute patent misuse.

\section{Reach-through royalties versus established licensing principles}

Traditionally, royalties are calculated based on the sales or uses of a patented product or process. However, parties may choose other 
methods of licensing a patented technology, such as flat fees or milestone payments, in the case of pre-commercialization licenses. Licenses to research tool patents present unique problems regarding the calculation of appropriate royalties. One complicating factor is that the ultimate commercial value of a patented research tool is as unpredictable as its prospects for successful application. As commentator Rebecca S. Eisenberg notes: "Licensing of patented inventions may pose special problems where the inventions are useful primarily for subsequent research rather than for commercial applications. The serendipitous nature of research discoveries may make it difficult to place a value on the right to use a patented invention before the outcome of a research project is known." 15

Of course, despite unpredictability, licenses will still be negotiated based on the expectations of the parties and their relative bargaining positions. The landmark GeorgiaPacific case ${ }^{16}$ provides a summary of the then current case law creating a framework for determining a reasonable royalty in a patent infringement action. Although GeorgiaPacific involved a method of determining a reasonable royalty by constructing a hypothetical licensing negotiation that might have occurred between parties before litigation, it sets out guidelines that are instructive in discussing how parties negotiate patent licenses in the real world. Of the 15 factors identified by the Georgia-Pacific court as relevant in determining a reasonable royalty, factors 8-10 are most pertinent here.

Factor eight refers to the established profitability of the product made under a patent. Profitability is difficult to assess when successful marketing of a patented technology, or a potential commercial derivative thereof, is uncertain and unpredictable. Research tool patentees often attempt to minimize the impact of this uncertainty by negotiating licenses based on a combination of both fixed fee payments geared to specific milestones in product development and reachthrough royalties on sales of the ultimate product. Prospective licensees, however, often understandably object to agreeing to pay royalties based on commercialized products that the patentee will play no role in developing ${ }^{17,18}$.

Factor nine concerns the utility and advantages of the patented technology over the prior $\operatorname{art}^{19}$. It involves considerations such as the superiority, efficiency, and expense of using the patented technology and the ability of the prospective licensee simply to design around the patent (using different research tools).

Factor ten is concerned with the nature of the patented invention, the character of its commercial embodiments, and its benefits to those who have used it ${ }^{19}$. These considerations are complicated by the unpredictability of research and development. In the context of research tool patents, the nature of the patented invention can be quite different from the character of many of its resulting commercial embodiments.

In sum, the unpredictability of the value licensed companies will derive from using patented research tools complicates the traditional framework for negotiating licenses. Creative solutions incorporating a mix of flat fees, milestone payments, and, perhaps, noncoercive reach-through royalties, may provide negotiators with some basis for hammering out a license beneficial to both parties.

\section{Recommendations for licensing research tool patents}

Those who develop novel and useful research tools should seek patent protection for their inventions by drafting applications containing detailed disclosures. The specifications of these patent applications should include examples of the various types of compounds and biomolecules that the patentee believes may be used in, or discovered by, the research tool, as well as representative species of those compounds or biomolecules. The specifications should also include as many working examples as possible to increase the likelihood that the application describes and enables commercial products on which the patentee can base its royalties.

Once patents are obtained, patentees should pursue licenses with those in the biotechnology or pharmaceutical industry whom they reasonably believe may be using or could use their technology to develop commercial products. In offering licenses, patentees should consider proposing royalty arrangements that include flat fees and milestone payments geared to specific stages of product development. Patentees may also consider proposing reach-through royalties based on sales of the ultimate commercial products. In doing so, patentees must be careful not to condition the licensing of the research tool claims on reach-through royalties based on products neither described nor enabled by their patent specifications. Such a "take it or leave it" approach in the absence of a reasonable argument that the patent claims should reach those commercial products may constitute patent misuse, rendering the patents unenforceable until the effects of that misuse have been mitigated.

Potential licensees may often have little choice but to take a license to patented research tools if (i) they intend to use those tools to discover or create commercial products, and (ii) after investigation, they believe that the patents are valid, enforceable, and cover the potential licensee's activities. Ignoring the potential need for such licenses today is tantamount to risking a patent infringement lawsuit, a finding of willful infringement, and substantial damages later if the products ultimately developed are commercially successful. However, in view of the current uncertainty concerning enforcement of research tool patents and the unpredictability of the value that they may bring to the prospective licensee, it may be possible to negotiate low royalty rates. As discussed above, the patent misuse doctrine provides prospective licensees with a basis for rejecting coercive reach-through royalty regimens that are not reasonably supported by the claims and specifications of the patents in question. Until the courts provide more guidance, we offer these recommendations to aid both sides in negotiations of research tool patent licenses to achieve mutually beneficial and enforceable arrangements.

1. Cullem, J.G. Panning for biotechnology gold: reach-through royalty damage awards for infringing uses of patented molecular sieves. Idea 39, 553 (1999).

2. 35 USC $\S 112$, first paragraph.

3. Genentech, Inc. v. Novo Nordisk et al., 108 F.3d 1361, 1366 (Fed. Cir. 1997).

4. Carroll, A.E. A review of recent decisions of the United States Court of Appeals for the Federal Circuit: comment: not always the best medicine: biotechnology and the global impact of US patent law. Am. U.L. Rev. 44, 2433, 2482-2483 (1995).

5. Zenith Radio Corp. v. Hazeltine Research, Inc., 395 US 100, 135-137 (1969).

6. Kobak, J.B. Intellectual property, competition law and hidden choices between original and sequential innovation. Va. J.L. \& Tech. 3, 6 at $\$ 23$ (citing Barton, J.H. Patents and antitrust: a rethinking in light of patent breadth and sequential innovation. Antitrust L.J. 65, 449, 454 (1997)).

7. Leitch Mfg. Co. v. Barber Co., 302 US 458, 463 (1938); See also B. Braun Medical Inc. v. Abbott Lab., 124 F.3d 1419, 1426 (Fed. Cir. 1997).

8. Zenith Radio Corp. v. Hazeltine Research, Inc., 395 US at 135 (1969)

9. Sibia Neurosciences, Inc. v. Cadus Pharmaceutical Corp., 225 F.3d 1349, 1354 (Fed. Cir. 2000).

10. Harpold, M.M. \& Brust, P. Assay methods and compositions useful for measuring the transduction of an intracellular signal. US patent 5,401,629 ("the '629 patent").

11. Sibia Neurosciences, Inc. v. Cadus Pharmaceutical Corp., 225 F.3d at 1357-1359.

12. Bayer AG and Bayer Corp. v. Housey Pharmaceuticals, Inc., 169 F.Supp 2d 328 (D. Del. 2001).

13. Idem at 329

14. Idem at 331

15. Eisenberg, R.S. Proprietary rights and the norms of science in biotechnology research. Yale L.J. 97, 177, 217 (1987).

16. Georgia-Pacific Corp. v. U.S. Plywood Corp., 318 F. Supp. 1116 (S.D.N.Y. 1970).

17. Eisenberg, R.S. Patents and the progress of science: exclusive rights and experimental use. U. Chi. L. Rev. 56, 1017, 1078 (1989)

18. Barton, J.H. Patents and antitrust: a rethinking in light of patent breadth and sequential innovation. Antitrust L.J. 65, 449 (1997)

19. Georgia-Pacific Corp. v. U.S. Plywood Corp., 318 F. Supp. at 1120. 